International Journal of Language Education

Volume 4, Number 2, 2020, pp. 301-313

ISSN: $2548-8457$ (Print) 2548-8465 (Online)

Doi: https://doi.org/10.26858/ijole.v4i2.13935

\title{
An in-Depth Exploration of EFL Teachers' Grammar Teaching Cognition
}

\author{
Khalegh Setoodeh \\ $\mathrm{PhD}$ Candidate, Department of Foreign Languages, Shiraz Branch, Islamic Azad \\ University, Shiraz, Iran \\ Email:myunique706@gmail.com \\ Esmaeil Jadidi \\ Department of Foreign Languages, Shiraz Branch, Islamic Azad \\ University, Shiraz, Iran \\ Corresponding author's email: esmaeil.jadidi@yahoo.com \\ Ehsan Rassaei \\ Department of English, Shiraz Branch, Islamic Azad University, Shiraz, Iran \\ Email: ehsanrassaei@gmail.com
}

Received: 05 June 2020

Reviewed: 1 August 2020 to 9 September 2020

Accepted: 1 October 2020

\begin{abstract}
L2 research, during the last two decades, has almost abandoned studying the appropriacy of methodologies and techniques to focus more on the underlying derives for teachers' pedagogical decision makings inside the class. Borg's (2003) ideas of the role of teachers' cognition in their adaptation and adoptation of teaching techniques and activities have noticeably influenced L2 professional research community. This study, in line with the recent trend, is designed and conducted to elicit EFL teachers' grammar teaching cognition to have more comprehensive accounts of teachers' behaviors in the class. In so doing, a Likert scale 25-item questionnaire developed by Naashia (2006) was administered to 177 Iranian EFL teachers. The results indicated that EFL teachers are currently more inclined toward communicative focus on grammar in which grammar instruction is marginalized to have learners naturally act out linguistics rules while performing communicative tasks.
\end{abstract}

Keywords: Teachers' grammar cognition, pedagogical decision makings, teaching approach, feedback and error correction

\section{Introduction}

Teachers' beliefs have been notoriously difficult to define and to study in the field of language teaching. They are also viewed as personally tacit constructs, theories, assumptions, and perceptions about teaching, learning, learners, and other aspects of teaching which can help understand their decisions and teaching practices (Kagan,1992; Pajares,1992; Richardson,1996). Some of these beliefs are fairly general while some are very specific. According to Johnson (1994) teachers' beliefs affect their decision making, perception, and the 
practical classroom activities which can lead to the improvement of teaching practices and teacher education programs. Moreover, they particularly guide teachers in the activities and practices they have in the classroom. There are different ways teachers may develop their beliefs which can be built up over time. These beliefs are derived from teachers' training programs, previous learning and teaching experiences, school practices, educational theory, individual personalities, and a number of other resources (Brog, 2003 and Richards, Gallo, and Renandya, 2001; Çapan, 2014). Eisentein-Ebsworth and Schweers (1997) declared that teachers' beliefs shaped by students' needs, syllabus expectations, and previous experiences. They may change over time as a result of teachers and students' interaction together with other influential factors. Researchers in second language acquisition have gotten interested in teachers' cognition and begun to examine language teachers' pedagogical beliefs in second language learning (Breen, 1991; Cumming, 1993; Freeman \& Richards; 1996; Johnson, 1994; Richards, 1998; Richards \& Nunan, 1990; Woods, 1996 Borg, 2018). Teacher beliefs are now viewed as a fairly complicated cognitive activity (Farrell and Patricia, 2005; Brog, 2003a, 2003b.; Mitchel and Hooper, 1992; Johnston, and Goettsch; 2000 Borg, \& Sanchez, 2020). Research into teachers' cognition has not only provided great insights into understanding teachers' cognition but also it can raise many important questions about some issues of teachers' beliefs.

One of the influential aspects of teachers' cognition in language teaching is teachers' beliefs about grammar and its different aspects (Borg, 2003). Grammar teaching has always created challenges and raised complex and fascinating pedagogical, linguistic and curricular issues. The advent of new methods or theories have always led to either the demise or enhance attention to grammar. Such variation affects the way language teachers develop different perspectives on grammar in the processes of becoming a teacher. During the last two decades, two strands of inquiry, one concentrating on the traditional practice of focus on forms and the other focusing on the issue of focus on form which has led to replacement of grammatical syllabus with more communicatively oriented ones.

\section{Literature review}

In the field of language teaching, a vast body of research has been done to examine teacher cognition for about the last two decades. It is also widely acknowledged that understanding teachers' cognitions plays a fundamental role in knowing what teachers do. The growing trend of teacher cognition has affected diverse domains of L2 teaching (Borg, 2006); amongst these, grammar teaching has received the focal attention.

Various studies in different contexts illustrate this view; Andrews (2007) in a number of studies in Hong Kong, found that teachers' grammatical knowledge plays a key role in their instructional decisions making when teaching it, while Borg (2001), in a case study in Malta, showed that teachers' actual knowledge of grammar together with their confidence of this knowledge influenced their way of teaching grammar. Regarding whether grammar should be taught in isolation or in combination with other language skills, more than $80 \%$ of teachers (176) were not in agreement in teaching grammar separately from other skills (Borg and Burns, 2008). Moreover, this body of research has indicated that the way teachers deal with grammar will be shaped by the interaction of their language learning beliefs, their perspectives on their learners' needs and wants, and other factors such as the availability of time (e.g., Farrell \& Lim, 2005). As a result of such interactions, what teachers do in the classroom may not necessarily be the reflection of their beliefs about the way grammar should be taught (see, e.g., Basturkmen, Loewen, \& Ellis, 2004; Sato \& Oyanedel, 2019). It is therefore significant in studies of teacher cognition to investigate not only teachers' theoretical beliefs (e.g., Jean \& Simard, 2011; Schulz, 1996) but how these are put into practice in various contexts in which teachers work (Pahissa \& Tragant, 2009 and Wang, \& Du, 2016 indicate the importance of contextual factors in teaching L2 grammar). 
A number of studies have examined teachers' implementation of communicative principles (e.g., Gorsuch, 2000, 2001; Kikuchi \& Browne, 2009; Nishino, 2008, 2011; Sakui, 2004, 2007; Sato \& Kleinsasser, 2004; Taguchi, 2005). Some of these studies such as Gorsuch (2000 and 2001) provide evidence that English teachers in Japan insist on valuing explicit grammar teaching in spite of the fact that institutional policies and teacher training initiatives were aimed at increasing the frequency of communicative- based activities in the classroom. Likewise, Gorsuch (2001) conducted a survey of 876 Japanese teachers of English and declared that while they slightly approved of communicative activities, teachers encountered some obstacles in using such activities in their classrooms. Similarly, Underwood (2012) put emphasis on the importance of such a phenomenon, although he brought the accuracy of the extent to which teachers' perceptions of some of these obstacles into question, as well. Moreover, this study suggested that the teachers (16 senior high school teachers of English in Japan) held positive beliefs about the integration of teaching grammar together with communicative-based language teaching activities.

There have been a number of studies on teachers' grammatical beliefs and grammar teaching. Ng \& Farrell (2003) and Yim (1993) examined the extent to which teachers' theoretical beliefs affected their classroom grammatical practices and found evidence to suggest that what teachers say and perform in the classroom are controlled by their beliefs. Farrell (1999) examined pre-service teachers' grammatical beliefs in terms of its influence on teaching practice and found evidence to indicate that these beliefs may be change-resistant. Similarly, Richards, Gallo, and Renandya (2001) investigated the grammatical beliefs of inservice teachers. The results of their study indicated that many teachers had a tendency to follow a communicative approach to teaching, while some of them stated that they firmly believed in the importance of direct and explicit grammar teaching.

Research has recently shown the effect of formal grammar teaching on some particular parts of grammar teaching; including inductive versus deductive approach to the teaching of grammar (Shaffer, 1989; Dekeyser, 1995), correcting errors and feedback (Chaudron, 1977; Dekeyser, 1993), use of grammar terminology in teaching grammatical points (Berman, 1979; Garrett, 1986), and the impact of grammar practice on L2 learning (Ellis, 1991; Johnson, 1994). Borg (2003) provides a comprehensive review of research into teachers' beliefs about grammar in the following areas; including, research into teachers' grammatical knowledge, teachers and learners' perspectives about formal instruction, and the implementation of the actual grammar teaching activities in their classes.

One strand of inquiry in English education contexts in UK has concentrated on insufficiencies of grammatical knowledge and of general understandings of prospective and practicing language teachers (e.g., Chandler, Robinson, \& Noyes 1988; Williamson \& Hardman 1995; Wray 1993). A further strand of inquiry has focused on similar issues in EFL contexts (Andrews 1994 and 1999a; Borg, 2001; Borg, 2015; Bellalem,2015). Based on a survey of 82 trainers in 1994 Andrews found that more than half of the trainees had insufficient levels of grammatical knowledge/awareness. Likewise, Andrews (1999a) used a 60-item test to compare the explicit knowledge of grammar and grammatical terminology of groups of native (UK) and non-native (Hong Kong) prospective and practicing language teachers and found that the non-native teachers of English did a better job on the test in comparison to other groups.

A vast analysis of teachers' viewpoints on grammar teaching was conducted by Eisenstein-Ebsworth \& Schweers (1997). To explore viewpoints about conscious grammar instruction, they used questionnaires with 60 ESL university teachers in New York and Puerto Rico together with informal interviews (with eight of these teachers). They found that most of the teachers tend to think of teaching grammar at least sometimes. Moreover, the Puerto Rico teachers had a strong tendency toward conscious grammar instruction than the New York group because of the advocacy of the more traditional approach to language teaching in Puerto Rico. 
The study also declared that teachers generally had personally well-defined approaches to teaching grammar in which they were confident. In expressing their coherent rationales, teachers referred to different factors such as student wants and syllabus expectations and more specifically it was their experience as teachers and learners that strongly influence on their perspective about grammar teaching, 'not research studies or any particular methodology' ( $\mathrm{p}$. 255).

Schulz (1996; 2001) examined both teachers and students' perspectives towards the role of grammar and error correction. Schulz (1996) compared grammar teaching beliefs and corrective feedback of 92 FL teachers and 824 language learners at an American university. The findings of this study were in line with Cathcart \& Olsen (1976) and McCargar (1993) which revealed significant mismatches between teachers and students' viewpoints about error correction; almost all of the students (94\%) disagreed with the statement 'teachers should not correct students when they make errors in class', while only $48 \%$ of teachers did. Schulz (2001) replicated his former study (Schulz,1996) with 122 FL teachers in Colombia, together with 607 of their students and found the results on this study were consistent with what was achieved in the previous study.

In order to examine the agreement concerning teacher and student cognitions, Berry (1997) investigated the knowledge of grammatical terminology of undergraduate students through a 50-item questionnaire in Hong Kong and found significant differences among students regarding 'knowledge of metalinguistic terms'. Moreover, he declared that teachers overestimated this knowledge (16 out of 50 items) which can lead to serious problems in the classroom.

Burgess \& Etherington (2002) examined grammatical and grammar teaching beliefs of 48 teachers of English for Academic purposes (EAP) through a questionnaire in the context of UK universities. Overall, he concluded that the teachers in this study had positive viewpoints towards formal instruction which can contribute to the improvement of their EAP students' language use and their proficiency levels. He declared that almost all teachers (over 90\%) stated that their students expected them to present explicit grammar points, and the teachers had positive inclinations towards this expectation.

The agreement between EAP students and teachers' viewpoints regarding explicit grammar teaching contrasts with what Schulz found above, although Schulz' study was based on data from both students and teachers, not just from teachers as in Burgess \& Etherington' EAP study. This difference indicates that comparisons between these two works should be made with the utmost caution.

Concerning the adoption of an inductive or a deductive approach to formal instruction, Farrell (1999) examined the past learning experience and personal grammar teaching perspective of pre-service teachers of English in Singapore and found that these trainees had a tendency to deal with grammar in the way they had been taught (inductively or deductively) because it was effective.

Brumfit, Mitchell, and Hooper (1996) described knowledge about language (KAL) practices in secondary English and Modern FL classrooms in the context of UK and recorded the evidences of teachers' views about language and about the role of this explicit knowledge in language education. They declared significant differences between English and FL teachers; FL teachers viewed KAL mainly in terms of sentential explicit grammar work. In contrast, English teachers adopted a text- based functional approach to language work. Moreover, they rarely used explicit grammar work and they indicated that using formal instruction is of slight importance to the development of students' overall linguistic ability (Mitchell et al. 1994b; Mitchell \& Hooper 1992). 
Overall, these findings together with Mitchell et al. 1994a indicate that theories of second-language acquisition, which play down the role of formal instruction in foreign language learning situations, have affected FL teachers relatively little.

In the exploration of the concept of teachers' metalinguistic awareness (TMA), Andrews (1997; 1999b) has illustrated connections between teachers' beliefs and practices in teaching grammar. Andrews (1997) explored the role of TMA in explaining grammar; he asked prospective teachers of English in Hong Kong to take part in a controlled role play in which they had to pinpoint formal errors in the text and subsequently give some explanations on these grammatical points to learners. Although the study put emphasis on weaknesses in the participants' KAL, Andrews argues that 'many of the apparent weaknesses in the performances seem to relate to metalinguistic awareness in operation rather than to problems with the underlying declarative KAL' (p. 160). For example, some teachers who specified errors in the text were not able to give explanations of these errors in the kind of language which could be useful to their learners.

The findings of such main studies as (Borg1998b; 1998c; 1999a; 1999c; 1999d; 2001; Johnston \& Goettsch 2000; Abu Rass, 2014) show that the decision in conducting explicit formal instruction does not necessarily suggest a belief on the part of the teacher that such instruction promotes language learning. Besides, teachers do not necessarily stick firmly to a specific approach (deductive and inductive) in teaching grammar; for instance, one of the teachers in Borg (1999c) made use of both deductive and inductive approaches in teaching grammar, defending her own way of doing this with reference to interacting and sometimes conflicting viewpoints based on her own teaching and learning experience.

The rationale underlying this study is that, teaching and learning grammar has always played a significant role in Iranian EFL context. Even with the advent of more communicative approaches to language teaching, grammar has been a pivot in class activities for both teachers and learners. The study can help arrive at a better understanding of the factors that may contribute to the development of the belief system or influence teachers' beliefs by examining perspectives of teachers about grammar. So, it aims to answer the following research question: What beliefs do Iranian English teachers in English language institutes hold about L2, its acquisition, and methods of instruction?

\section{Research Design}

Classroom based educational research employs qualitative and quantitative designs, or a combination of both. The difference between the two, as Best \& Kahn (1998) describe, is in numbers. Qualitative research consists of observing and asking with the purpose of describing actions and individuals carefully to gain a profound and full understanding of the phenomenon under investigation without analyzing them. In contrast, quantitative research is concerned with measuring numerical data which are of paramount importance. The main and the most outstanding feature of quantitative research is that it is capable of quantifying variables which can be generalizable. Besides, it can measure factors in terms of quantity, degree or frequency. Moreover, due to some limitations and the teachers' willingness to fill out a questionnaire- based study, the present study employs a quantitative research design; that is, it aims to describe systematically, factually and accurately teachers' grammar beliefs and attitudes in English language classrooms through a questionnaire.

\section{Participants}

A total of 177 Iranian EFL English teachers, who participated in this study, were randomly selected. They teach English at language institutes in Fars province, Iran. They were 
both male and females. They ranged from 23 to 40 years of age. As to their teaching experiences, all participants had at least a minimum of 3 and maximum of 14 years of teaching experience. All teachers had BA or MA degree in teaching English.

\section{Instruments}

A questionnaire is a self-report instrument useful for economically and speedily obtaining data from a large number of respondents (Brown, 2001). In the study of teachers' beliefs and practices, questionnaires have made regular appearances (e.g. MacDonald, Badger, \& White, 2001). A 24-item questionnaire, developed by Naashia Mohamed (2006), required teachers to respond to statements on a five-point Likert scale in the present study. The beliefs questionnaire used for this study was designed to fulfil two main objectives. Firstly, it tries to pinpoint the beliefs teachers had concerning grammar and its role in language learning and teaching. Secondly, the questionnaire aimed to obtain information about teachers' reported classroom practices regarding the teaching of grammar. In general, teachers' beliefs questionnaire was divided into five main components: teaching approach, importance of grammar, role of the learner in learning grammar, arguments against teaching grammar, and feedback and error correction. The validity of the questionnaire was established through a review by a group of university teachers together with some $\mathrm{PhD}$ candidates.

\section{Data collection procedure}

The questionnaire was distributed among language teachers at institutes where they taught. Teachers took the questionnaire either before or after their class time. They were required to choose the option that best explains their beliefs. The researcher sent some of the questionnaires $(30 \%)$ through an email because they taught at different institute across Fars province. Still some teachers were allowed to take questionnaire home to complete. All the teachers had to select strongly disagree (SD), disagree (D), neutral (Ne), agree(A), and strongly agree (SA) for each of the items in the questionnaire. Teachers' beliefs as stated in the questionnaire were then scored and summarized on the basis of the five main components of beliefs questionnaire.

\section{Data analysis procedures}

Seven experts including experienced university teachers and experienced observers were asked to review each item of the questionnaire closely to support the content validity of the questionnaires. Five EFL experienced teachers responded to the questionnaire; then the teachers were asked to comment on the items by signifying the questions which were in some way vague. As a result, the necessary revisions were made for each of the ambiguous item. Besides, concerning both teachers' grammar beliefs questionnaire reliability coefficient which is the scale used to measure reliability of the questionnaire was calculated using Cronbach alpha. The answer to each item of the beliefs questionnaire was transformed into SPSS 22. A descriptive analysis was done concerning the provided answers for each item of the five component of the questionnaire to interpret the data; the results are provided in the results section.

\section{Results and Discussion}

Larsen-Freeman (2007) declared that teachers teach subjects based on their understanding. What teachers try to do in their actual classroom teaching comes from many factors including their experiences, their teaching philosophy, and contextual factors. This 
issue is important because language teachers' beliefs influence their choice of teaching methods. Teachers' beliefs are the words they use to explain what they think they actually do in the classroom. Argyris (1980) highlighted that the best result can be achieved in case of compatibility between beliefs and behaviors.

Much research has been done on figuring out the perspectives and attitudes on second or foreign language teachers and learners (Arikan, 2011; Navarro \& Thornton, 2011; Peng, 2011), but the number of studies concerning teachers' beliefs is not enough (Peacock, 2001), particularly EFL teachers' grammar beliefs. Borg (2009) stated that few studies have been done on teachers' beliefs in English Language Teaching (ELT). Besides, because the number of NNSs who teach English is more than NS teachers (Lin 1999), and that the number of EFL learners is more than their ESL counterparts (Graddol 1997), the current research needs to be done in relatively many more language teaching contexts across the world. Because of such gaps in the literature, Borg (2003) indicated that there is a very important need to do research on NN L2 teachers' beliefs in the environments other than developed countries. While significant attempts have been made to understand the relationship between teachers' beliefs and practices in the L1 context, the studies examining teachers' beliefs in the EFL contexts have been limited (Borg, 2006). As Borg (2003) rightly declared that teachers' beliefs may be shaped by their cognitive characteristics, learning and teaching experiences, and their professional behaviors.

Research Question

What beliefs do Iranian English teachers in English language institutes hold about L2 grammar, its acquisition and methods of instruction?

As the data were collected by a questionnaire on a Likert scale, it could allow calculation of the descriptive statistics for each single item of the questionnaire and the five main components of teachers' beliefs about grammar. Component 1 deals with different aspects of teaching grammar and hence is the strongest of five components. Table 1 . shows the frequency counts and percentage for each item in this component.

Table 1: Descriptive Statistics for Component 1, Teaching Approach (T A).

\begin{tabular}{|c|c|c|c|c|c|c|c|}
\hline No. & Description & $\mathrm{N}$ & SD & $\mathrm{D}$ & $\mathrm{Ne}$ & $\mathrm{SA}$ & $\mathrm{A}$ \\
\hline \multirow[t]{2}{*}{11} & \multirow{2}{*}{$\begin{array}{l}\text { It is essential that students are } \\
\text { familiar with the correct } \\
\text { grammatical terminology }\end{array}$} & 177 & 8 & 57 & 34 & 50 & 28 \\
\hline & & $100 \%$ & $4.53 \%$ & $32.2 \%$ & $19.2 \%$ & $28.2 \%$ & $15.8 \%$ \\
\hline \multirow[t]{2}{*}{21} & \multirow{2}{*}{$\begin{array}{l}\text { Students will learn grammar better if } \\
\text { they understand grammatical } \\
\text { terminology. }\end{array}$} & 177 & 11 & 44 & 22 & 66 & 34 \\
\hline & & $100 \%$ & $6.2 \%$ & $24.9 \%$ & $12.4 \%$ & $37.3 \%$ & $19.2 \%$ \\
\hline \multirow[t]{2}{*}{23} & \multirow{2}{*}{$\begin{array}{l}\text { The main role of the teacher in a } \\
\text { grammar lesson is to explain the } \\
\text { grammar point. }\end{array}$} & 177 & 14 & 63 & 25 & 57 & 18 \\
\hline & & $100 \%$ & $7.9 \%$ & $35.6 \%$ & $14.1 \%$ & $32.2 \%$ & $10.2 \%$ \\
\hline \multirow[t]{2}{*}{7} & \multirow{2}{*}{$\begin{array}{l}\text { Grammar should be the main } \\
\text { component of any teaching syllabus. }\end{array}$} & 177 & 20 & 66 & 8 & 48 & 35 \\
\hline & & $100 \%$ & $11.3 \%$ & $37.3 \%$ & $4.5 \%$ & $27.1 \%$ & $19.8 \%$ \\
\hline \multirow[t]{2}{*}{4} & \multirow{2}{*}{$\begin{array}{l}\text { Grammar can be successfully taught } \\
\text { without extensive grammatical } \\
\text { terminology. }\end{array}$} & 177 & 19 & 20 & 13 & 78 & 46 \\
\hline & & $100 \%$ & $10.7 \%$ & $11.3 \%$ & $7.3 \%$ & $44.1 \%$ & $26 \%$ \\
\hline \multirow[t]{2}{*}{9} & \multirow{2}{*}{$\begin{array}{l}\text { It is best to teach grammar } \\
\text { intensively rather than extensively. }\end{array}$} & 177 & 21 & 68 & 13 & 45 & 30 \\
\hline & & $100 \%$ & $11.9 \%$ & $38.4 \%$ & $7.3 \%$ & $25.4 \%$ & $16.9 \%$ \\
\hline
\end{tabular}




\begin{tabular}{llllllll}
14 & $\begin{array}{l}\text { It is important to focus on grammar } \\
\text { in all lessons. }\end{array}$ & 177 & 21 & 59 & 20 & 54 & 23 \\
22 & $100 \%$ & $11.9 \%$ & 33.3 & $11.3 \%$ & $30.5 \%$ & $13 \%$ \\
\hline $\begin{array}{l}\text { Teachers should begin a grammar } \\
\text { lesson by explaining how the }\end{array}$ & 177 & 14 & 52 & 22 & 67 & 22 \\
$\begin{array}{l}\text { structure works. } \\
16\end{array}$ & $\begin{array}{l}\text { It is more important to teach } \\
\text { grammar to beginners than to } \\
\text { advanced learners. }\end{array}$ & $100 \%$ & $7.9 \%$ & $29.4 \%$ & $12.4 \%$ & $37.9 \%$ & $12.4 \%$ \\
\hline
\end{tabular}

Note. No. refers to the number in the original questionnaire. $\mathrm{N}=$ Number of responses. SD $=$ Strongly Disagree, $\mathrm{D}=$ Disagree; $\mathrm{Ne}=$ Neutral, $\mathrm{A}=$ Agree, $\mathrm{SA}=$ Strongly Agree. $\%$ refers to the percentages .

It can be seen from the table 1 . that teachers generally agree /strongly agree with items number $11(44 \%)$ and $21(56.5 \%)$ which are about knowledge of grammatical terminology. This is in line with what Andrews (2007) found the key importance of knowledge of grammatical terminology in a number of studies in an EFL context of Hongkong. Teachers disagree/ strongly disagree with item No.9 (50.3\%) it is better to teach grammar intensively rather than extensively which is in contrast with item No.4 Grammar can be successfully taught without extensive grammatical terminology in which teachers strongly agree/ agree with (71.1\%). Regarding statement 7 , close to half of the teachers $48.6 \%$ believed that grammar should not be the main component of any teaching syllabus this may due to the fact that they believe in a communicative based language teaching or due to institutional policies in some language schools. Likewise, $45.2 \%$ of the teachers disagree with item No. 14 It was important to focus on grammar in all lessons. $58.7 \%$ of teachers agreed with statement 16 , the importance of teaching grammar to beginners than advanced learners, because beginner learners are not advanced enough to deal with grammar on their own.

Table 2: Descriptive Statistics for Component 2, Arguments Against Grammar Teaching (AAGT)

\begin{tabular}{llllllll}
\hline No. & Description & $\mathrm{N}$ & $\mathrm{SD}$ & $\mathrm{D}$ & $\mathrm{Ne}$ & $\mathrm{SA}$ & $\mathrm{A}$ \\
\hline 1 & $\begin{array}{l}\text { A learner can acquire a second or foreign } \\
\text { language without grammar instruction. }\end{array}$ & 177 & 18 & 40 & 7 & 74 & 38 \\
& & $100 \%$ & $10.2 \%$ & $22.5 \%$ & $4 \%$ & $41.8 \%$ & $21.5 \%$ \\
5 & $\begin{array}{l}\text { Grammar is best acquired unconsciously } \\
\text { through meaningful communication. }\end{array}$ & 177 & 11 & 42 & 7 & 81 & 36 \\
\multirow{2}{*}{6} & $\begin{array}{l}\text { Grammar is best learned naturally through } \\
\text { trying to communicate }\end{array}$ & $100 \%$ & $6.2 \%$ & $23.7 \%$ & $4 \%$ & $45.7 \%$ & $20.3 \%$ \\
& & $100 \%$ & $4.5 \%$ & $19.7 \%$ & $5.1 \%$ & $27.1 \%$ & $43.5 \%$ \\
\hline
\end{tabular}

Note. No. refers to the number in the original questionnaire. $\mathrm{N}=$ Number of responses. $\mathrm{SD}=$ Strongly Disagree, $\mathrm{D}=$ Disagree; $\mathrm{Ne}=$ Neutral, $\mathrm{A}=$ Agree, $\mathrm{SA}=$ Strongly Agree. $\%$ refers to the percentages.

It can be seen from table 2 that teachers had strong responses to these statements. The most important point about this component is that a small number of teachers chose the neutral position for all three statements. About half of the teachers strongly agree/ agree with item No.1 in which they did not believe in grammar instruction. Teachers were in agreement about the grammar acquisition through natural and meaningful communication in statements 5 and 6 which supports Krashen (1988) and what Richards, Gallo, and Renandya (2001) among others found that many teachers tend to follow a communicative approach to teaching.

The three statements in component 3 , shown in table 3 . below, deal with feedback and error correction. The most noticeable fact about this component is that the vast majority of teachers $87 \%$ either agreed/ strongly agreed with item No. 12, It is important for students to be 
given the right answers after an exercise/test. Concerning statement 13 , more than $55 \%$ of the teachers disagreed/strongly disagreed with correcting all grammatical errors in oral activities. This may due to the fact that teaching grammar hinders fluency. On the other hand, $67 \%$ of them strongly agreed/ agreed with identifying all grammatical errors in students' written work. This is in line with what Teachers in (Burgess \& Etherington, 2002; Richards, Gallo, \& Renandya, 2001; Schulz, 1996) claimed that accuracy was far more important than fluency which was associated almost exclusively with speaking skills and therefore was not considered a priority in EFL contexts such as Maldivian schools and examinations. Moreover, errors in writing could be identified and commented on more easily.

Table 3: Descriptive Statistics for Component 3, Feedback and Error Correction (FEC)

\begin{tabular}{llllllll}
\hline No. & Description & $\mathrm{N}$ & $\mathrm{SD}$ & $\mathrm{D}$ & $\mathrm{Ne}$ & $\mathrm{SA}$ & $\mathrm{A}$ \\
\hline 12 & $\begin{array}{l}\text { It is important for students to be given } \\
\text { the right answers after an exercise/test. }\end{array}$ & 177 & 5 & 7 & 11 & 86 & 68 \\
13 & $100 \%$ & $2.8 \%$ & $4 \%$ & $6.2 \%$ & $48.6 \%$ & $38.4 \%$ \\
& $\begin{array}{l}\text { It is important to correct all } \\
\text { grammatical errors in students' oral }\end{array}$ & 177 & 11 & 87 & 5 & 49 & 25 \\
$\begin{array}{l}\text { work. } \\
15\end{array}$ & $100 \%$ & $6.2 \%$ & $49.2 \%$ & $2.8 \%$ & $27.7 \%$ & $14.1 \%$ \\
$\begin{array}{l}\text { It is important to identify all } \\
\text { grammatical errors in students' written } \\
\text { work }\end{array}$ & 177 & 11 & 25 & 19 & 75 & 47 \\
& & $6.2 \%$ & $14.1 \%$ & $10.7 \%$ & $42.4 \%$ & $26.6 \%$
\end{tabular}

Note. No. refers to the number in the original questionnaire. $\mathrm{N}=$ Number of responses. SD $=$ Strongly Disagree, $\mathrm{D}=$ Disagree; $\mathrm{Ne}=$ Neutral, $\mathrm{A}=$ Agree, $\mathrm{SA}=$ Strongly Agree. $\%$ refers to the percentages .

Teachers strongly agreed/agreed with all five statements included in component 4 importance of grammar. As it can be seen from table 4., more than $74 \%$ of the teachers responded positively to item No. 8 If learners receive grammar instruction, they are more likely to be able to correct errors. This tallies Swain noticing hypothesis in which if learners receive instruction, they notice the correct form and hence reformulate their errors. About $79 \%$ of the teachers strongly agree or agree with statement 2 Attention to grammar ensures that students become aware of how the language works. This matches up what Clark \& Peterson (1986) declared to be a "resilient or core belief" that attention to explicit grammar instruction should be the main focus of any teaching syllabus and that it was significant to concentrate on grammar in all lessons. Teachers responded positively $77.6 \%$ to statement 3 Explicit knowledge of grammatical rules is essential for the mastery of language. This lends support to other studies of teachers' beliefs (Burgess \& Etherington, 2002; Richards, Gallo, \& Renandya, 2001; Schulz, 1996) which showed that teachers had a general tendency towards explicit grammar instruction.

Table 4: Descriptive Statistics for Component 4, Importance of Grammar (IG).

\begin{tabular}{|c|c|c|c|c|c|c|c|}
\hline No. & Description & $\mathrm{N}$ & SD & $\mathrm{D}$ & $\mathrm{Ne}$ & SA & A \\
\hline \multirow[t]{2}{*}{8} & \multirow{2}{*}{$\begin{array}{l}\text { If learners receive grammar instruction, } \\
\text { they are more likely to be able to correct } \\
\text { errors. }\end{array}$} & 177 & 14 & 16 & 15 & 73 & 59 \\
\hline & & $100 \%$ & $7.9 \%$ & $9 \%$ & $8.5 \%$ & $41.2 \%$ & $33.3 \%$ \\
\hline \multirow[t]{2}{*}{17} & \multirow{2}{*}{$\begin{array}{l}\text { Regular practice ensures that grammar is } \\
\text { quickly and successfully acquired. }\end{array}$} & 177 & 10 & 13 & 8 & 91 & 55 \\
\hline & & $100 \%$ & $5.6 \%$ & $7.3 \%$ & $4.5 \%$ & $51.4 \%$ & $31.1 \%$ \\
\hline \multirow[t]{2}{*}{2} & \multirow{2}{*}{$\begin{array}{l}\text { Attention to grammar ensures that } \\
\text { students become aware of how the } \\
\text { language works }\end{array}$} & 177 & 12 & 13 & 12 & 75 & 65 \\
\hline & & $100 \%$ & $6.8 \%$ & $7.3 \%$ & $6.8 \%$ & $42.4 \%$ & $36.7 \%$ \\
\hline
\end{tabular}


3 Explicit knowledge of grammatical rules is essential for the mastery of language.

$\begin{array}{llllll}177 & 21 & 20 & 00 & 51 & 85 \\ 100 \% & 11.9 \% & 11.3 \% & 00 & 28.8 \% & 48 \% \\ 177 & 15 & 18 & 17 & 81 & 46 \\ 100 \% & 8.5 \% & 10.2 \% & 9.6 \% & 45.8 \% & 26 \%\end{array}$

Note. No. refers to the number in the original questionnaire. $\mathrm{N}=$ Number of responses. $\mathrm{SD}=$ Strongly Disagree, $\mathrm{D}=$ Disagree; $\mathrm{Ne}=$ Neutral, $\mathrm{A}=$ Agree, $\mathrm{SA}=$ Strongly Agree. $\%$ refers to the percentages.

As it is shown in table 5. below, component 5 deals with role of the learner in learning grammar. The most outstanding feature of this component is that more than $87 \%$ of the teachers either strongly agreed or agreed with item No. 20 in which students should be given the opportunity to work out rules from examples. This is in line with (Shaffer, 1989 and Dekeyser, 1995) among others who declared that students can benefit more from an inductive approach to teaching grammar. However, Borg(1998c) and Johnston \& Goettsch (2000) declared that teachers do not necessarily follow a specific approach (deductive and inductive) in teaching grammar.

Table 5: Descriptive Statistics for Component 5, Role of the Learner in Learning Grammar (RLLG).

\begin{tabular}{llllllll}
\hline No. & \multicolumn{1}{c}{ Description } & \multicolumn{1}{c}{$\mathrm{N}$} & $\mathrm{SD}$ & $\mathrm{D}$ & $\mathrm{Ne}$ & $\mathrm{SA}$ & $\mathrm{A}$ \\
\hline 10 & $\begin{array}{l}\text { It is better for students to figure out for } \\
\text { themselves why their answer was }\end{array}$ & 177 & 8 & 8 & 22 & 77 & 62 \\
& $100 \%$ & $4.5 \%$ & $4.5 \%$ & $12.4 \%$ & $35.2 \%$ & $35 \%$ \\
18 & $\begin{array}{l}\text { wrong. } \\
\text { Students generally do not learn the } \\
\text { grammatical structures they are taught. }\end{array}$ & 177 & 54 & 67 & 15 & 24 & 17 \\
19 & $\begin{array}{l}\text { Students rarely become error-free } \\
\text { because English grammar is very } \\
\text { complex. }\end{array}$ & 177 & 16 & 17 & 19 & 74 & 51 \\
20 & $\begin{array}{l}\text { Students should be given the opportunity } \\
\text { to work out rules from examples. }\end{array}$ & 177 & 8 & 5 & 7 & 90 & 67 \\
\hline
\end{tabular}

Note. No. refers to the number in the original questionnaire. $\mathrm{N}=$ Number of responses. SD $=$ Strongly Disagree, $\mathrm{D}=$ Disagree; $\mathrm{Ne}=$ Neutral, $\mathrm{A}=$ Agree, $\mathrm{SA}=$ Strongly Agree. $\%$ refers to the percentages.

The analysis of the five components of the grammar beliefs questionnaire generally reveals that teachers have the inclination to teach grammar in all lessons though not be the main component of any teaching syllabuses; in so doing, they put emphasis on understanding the grammar terminology and the importance of concentrating on grammar in all lessons. The findings also show that teachers believe in teaching grammar through communication; this may mean that teachers believe in communicative-based activities in an EFL context.

Moreover, concerning the feedback and error correction, teachers have a general tendency to provide feedback and the corrected form though with different degrees; for example, in speaking and writing skills. Besides, the results above show that teachers believe in the importance of teaching and the practicing of the grammar lesson to help learners to be competent to produce more complex sentences. Furthermore, teachers believed in allowing the learners themselves to come across the correct answer and in providing the opportunities for learners to elicit rules from the samples; these are in line with learner-centered way of learning a language. 


\section{Conclusion}

The bulk of L2 research has been done for the last few decades on teachers' beliefs about teaching and learning grammar which is important because according to Fazio and Zanna (1981), beliefs have a direct impact on behavior. On the other hand, by considering the Action Theory (Argyris \& Schön, 1984), the congruity between teaching beliefs and practices is very important; If there is no compatibility between beliefs and practices, there won't be good achievements. Furthermore, what underlies teachers' decision makings in accepting and applying various teaching techniques and activities have markedly affected L2 professional research community (Borg, 2003 and Yuan \& Lee, 2014). Therefore, the present study is done to manipulate Iranian EFL teachers' grammar cognition in order to have a thorough understanding of teachers' behaviors and practices in the classroom. In so doing, a 24-item questionnaire on a Likert scale developed by Naashia (2006) was administered to 177 Iranian EFL teachers. The results revealed that EFL teachers have predispositions in concentrating on a communicative way of teaching grammar. Besides, in order to assist learners to be naturally competent in using linguistics while performing communicative activities.

Declaration of conflicting interest

The author(s) declare(s) that there is no conflict of interest.

Funding Acknowledgment:

The author(s) received no financial support for the research, authorship, and/or publication of this article.

\section{References}

Abu Rass, R. (2014). Developing reflective skills among EFL student teachers. International Journal of English Language Teaching, 2(3), 1-14.

Andrews, S. (1997). Metalinguistic awareness and teacher explanation. Language Awareness, 6(2\&3), 147-161.

Andrews, S. (2007). Teacher language awareness. Cambridge: Cambridge University Press.

Argyis, C., \& Schon, D. (1974). Theory in practice: increasing professional effectiveness. San Francisco:Jossey-Bass.

Basturkmen, H., Loewen, S., \& Ellis, R. (2004). Teachers' stated beliefs about incidental focus on form and their classroom practices. Applied Linguistics, 25(2), 243-272

Bellalem, F. (2015). The study of foreign language teachers' beliefs: implications for research in the Arab world. English Lingua Journal, 1(1), 91-106.

Borg, M. (2001). Teachers' beliefs. ELT Journal, 55(2), 186-187.

Borg, S. (2018). Teachers' beliefs and classroom practices. In P. Garrett \& J. Cots (Eds.), The Routledge handbook of language awareness (pp. 75-91). London: Routledge.

Borg, S. (2018). Teacher evaluation: Global perspectives and their implications for English language teaching. A literature review. Delhi: British Council.

Borg, S. (2015). The study of teacher cognition. Shanghai: SFLEP.

Borg, S. (2015). Researching teacher beliefs. In B. Paltridge \& A. Phakiti (Eds.), Research methods in applied linguistics: A practical resource (pp. 487-504). London: Bloomsbury.

Borg, S. (2012). Interview "Teacher cognition \& language teacher education: beliefs \& practice". A conversation with Simon Borg. Berratella Journal of Language Teaching \& Learning Language \& Literature, 5 (2), 88-94.

Borg, S. (2011). The impact of in-service teacher education on language teachers' beliefs. System, 39, 370-380.

Borg, S. (2006). Teacher cognition \& language education. London: Continuum. 
Borg, S. (2005). Experience, knowledge about language \& classroom practice in teaching grammar. In N. Bartels (Ed.), Applied linguistics \& language teacher education (pp. 325340). New York: Springer.

Borg, S. (2003). Teacher cognition in language teaching: A review of research on what language teachers think, know, believe, \& do. Language Teaching, 36(2), 81-109.

Borg, S. (2001). Self-perception \& practice in teaching grammar. ELT Journal, 55(1), 21-9.

Borg, S. (1997). Unifying concepts in the study of teachers' cognitive structures. Unpublished manuscript.

Borg, S. (1998a). Talking about grammar in the foreign language classroom. Language Awareness, 7(4), 159-175.

Borg, S. (1998b). Teachers' pedagogical systems and grammar teaching: a qualitative study. TESOL Quarterly, 32(1), 9-38.

Borg, S. (1999a). Studying teacher cognition in second language grammar teaching. System, 27(1), 19-31.

Borg, S. (1999b). Teachers' theories in grammar teaching. ELT Journal, 53(3), 157167.

Borg, S. (1999c). The use of grammatical terminology in the second language classroom: a qualitative study of teachers' practices and cognitions. Applied Linguistics, 20(1), 95-126.

Borg, S. (2001). Self-perception and practice in teaching grammar. ELT Journal, 55(1), 21-29.

Borg, S. (2003). Teacher cognition in language teaching: a review of research on what language teachers think, believe, know and do. Language Teaching, 36, 81-39.

Borg, S. (2006). The distinctive characteristics of foreign language teachers.

Language Teaching Research, 10(1), 3-31.

Borg, S., \& Sanchez, H. S. (2020). Cognition and good language teachers. In C. Griffiths \& Z. Tajeddin (Eds.), Lessons from good language teachers (pp. 16-27). Cambridge University Press

Breen, M. P., Hird, B., Milton, M., Thwaite, A., \& Oliver, R. (2001). Making sense of language teaching: teachers' principles and classroom practices. Applied Linguistics, 22(4), 470-501.

Brumfit, C., Mitchell, R., \& Hooper, J. (1996). Grammar, language and classroom practice. In M. Hughes (Ed.), Teaching and learning in changing times. Oxford: Blackwell.

Burgess, J., \& Etherington, S. (2002). Focus on grammatical form: explicit or implicit? System, 30, 433-458.

Burns, A. (1990). Focus on language in the communicative classroom. In G. Brindley (Ed.), The second language curriculum in action. Sydney: National Centre for English Language Teaching and Learning.

Çapan, S. A. (2014). Pre-service English as a Foreign language teachers' belief development about grammar instruction. Australian Journal of Teacher Education, 39(12), 131-152.

Clark, C. M., \& Peterson, P. L. (1986). Teachers' thought processes. In M. C. Wittrock (Ed.), Handbook of research on teaching (3rd ed.). New York: Macmillan.

Johnston, B., \& Goettsch, K. (2000). In search of the knowledge base of language teaching: Explanations by experienced teachers. Canadian Modern Language Review, 56, 437- 468.

Johnson, K. E. (1994). The emerging beliefs and instructional practices of preservice English as a second language teachers. Teaching \& Teacher Education, 10(4), 439-452.

Kagan, D. M. (1992). Implications of research on teacher belief. Educational Psychologist, 27(1), 65-90. 
Krashen, S. D. (1982). Principles and practice in second language acquisition (1 $1^{\mathrm{st}}$ ed.). Oxford ; New York: Pergamon).

Mohamed, N. (2006). An exploratory study of the interplay between teachers' beliefs, instructional practices \& professional development (Unpublished doctoral dissertation). The University of Auckland, Auckland.

Pajares, M. F. (1992). Teachers' beliefs \& educational research: Cleaning up a messy construct. Review of Educational Research, 62, 307-332.

Richardson, V. (1996). The role of attitudes and beliefs in learning to teach. In J. Sikula (Ed.), Handbook of research on teacher education (2nd Edition ed., pp. 102-119). New York: Macmillan.

Richards, J. C., Gallo, P. B., \& Renandya, W. A. (2001). Exploring teachers' beliefs and the processes of change. The PAC Journal, 1(1), 41-62.

Sato, M., \& Oyanedel, J. C. (2019). "I think that is a better way to teach but ...": EFL teachers' conflicting beliefs about grammar teaching. System, 84, 110-122. https://doi.org/10.1016/j.system.2019.06.005

Schulz, R. A. (1996). Focus on form in the foreign language classroom: students' and teachers' views on error correction and the role of grammar. Foreign Language Annals, 29(3), 343-364.

Schulz, R. A. (2001). Cultural differences in student and teacher perceptions concerning the role of grammar instruction and corrective feedback: USA Colombia. The Modern Language Journal, 85(2), 244-258.

Woods, D (1996). Teacher cognition \& language teaching. New York: Cambridge University Press

Wang, L., \& Du, X. (2016). Chinese language teachers' beliefs about their roles in the Danish context. System, 61, 1-11. https://dx.doi.org/10.1016/j.system.2016.06.009

Yuan, E. R., \& Lee, I. (2014). Pre-service teachers' changing beliefs in the teaching practicum: Three cases in an EFL context. System, 44, 1-12. https://doi.org/10.1016/j.system.2014.02.002 